\title{
A SUBCLASS OF ANALYTIC FUNCTIONS RELATED WITH CONIC DOMAIN
}

\author{
Mamoru NunOKaWA, SAQib Hussain, NAZAR KHAN \\ AND QAZI ZAHOOR AHMAD
}

\begin{abstract}
In this paper, we introduce a new subclass of analytic functions by using the concept of conic domain. We prove inclusion relations, a characterization theorem, coefficient inequalities, a distortion theorem, a covering theorem, and the radii of close-to-convexity, startlikeness and convexity for this class of functions.
\end{abstract}

Mathematics subject classification (2010): 30C45, 30C50.

Keywords and phrases: Analytic functions, uniformly convex functions, uniformly starlike functions, operators, conic domain.

\section{REFERENCES}

[1] B. C. CARlson, S. B. ShafFer, Starlike and prestarlike hypergeometric functions, SIAM J. Math. Anal. 15 (2002), 737-745.

[2] P. L. DuREN, Univalent Functions, Springer-Verlag, New York, 1983.

[3] J. DZIOK, H. M. SRIVASTAVA, Certain subclasses of analytic functions associated with the generalized hypergeometric functions, Integral Transform and Spec. Funct. 14 (2003), 7-18.

[4] P. Eeingenburg, S. S. Miller, P. T. Mocanu, M. O. Reade, General Inequalities, Birkhauseverlag-Basel, ISNM, 64 (1983), 339-348.

[5] A. W. Goodman, On uniformly starlike functions, J. Math. Anal. Appl. 155 (1991), 364-370.

[6] A. W. Goodman, On uniformly convex functions, Ann. Polon. Math. 56 (1991), 87-92.

[7] A. W. Goodman, Univalent Functions, vols. I, II, Plygonal Publishing House, Washington New Jersey (1983).

[8] S. Kanas, A. Wisniowska, Conic regions and k-uniform convexity, J. Comput. Appl. Math. 105 (1999), 327-336.

[9] S. Kanas, A. Wisniowska, Conic domains and starlike functions, Rev. Roumaine. Math. Pures Appl. 45 (2000), 647-657.

[10] S. KANAS, Techniques of the differential subordination for domains bounded by conic sections, Int. J. Math. Math. Sci., 38 (2003), 2389-2400.

[11] S. Kanas, T. Sugawa, On conformal representation of the interior of an ellipse, Ann. Acad. Sci. Fenn. Math. 31 (2006), 329-34.

[12] J. L. LiU, K. I. NooR, Some properties of Noor integral operator, J. Nat. Geom., 21 (2002), 81-90.

[13] W. MA, D. MK, A unified treatment of some special classes of univalent functions, Proceeding of the confrence of complex analysis (Tiajin), Conf. Proc. Lecture Notes Anal., International Press, Massachusetts, (1992), 157-169.

[14] K. I. NoOR, M. ARIF, M. W. Ul-HaQ, On k-uniformly close-to-convex functions of complex order, Appl. Math. Comput. 215 (2009), 629-635.

[15] K. I. NoOR, S. MALIK, On coefficient inequalities of functions associated with conic domains, Comput. Math. Appl. 62 (2011), 2209-2217.

[16] B. PInChuK, On starlike and convex functions of order $\alpha$, Duke Math. J. 35 (1968), 721-734.

[17] F. Ronning, On starlike functions assicated with parabolic regions, Ann. Univ. Mariae CurieSklodowska, Sect A., 45 (1991), 117-122. 
[18] S. Shams, S. R. Kulkarni, J. M. Jahangiri, Classes of uniformly starlike and convex functions, Int. J. Math. Math. Sci., 55 (2004), 2959-2961.

[19] H. SAIтоH, A linear operator and its application of first order differential subordinations, Math. Japan, 44 (1996), 31-38.

[20] H. Silverman, Univalent functions with negative coefficients, Proc. Amer. Math. Soc. 51 (1975), $109-116$. 